\title{
Effects of $R \& D$ and networking on the export decision of Japanese firms
}

Revised: 11October, 2006; First version: 29 October, 2004

\section{Eiichi Tomiura*}

Department of Economics, Yokohama National University, Yokohama, 240-8501, Japan

\begin{abstract}
This paper examines how internal R\&D intensity and external networking channels are related with the firm's export decision, based on a large firm-level data set covering all manufacturing industries in Japan without any firm-size threshold. Internal $R \& D$ is not the only determinant of exporting, while it is strongly related with exports in the science-based sector. Collaborations with other firms on joint projects and operations of subsidiaries overseas are significantly linked to exports of large-sized firms, while affiliations with business associations and R\&D intensity are critical for small-sized firms to export. Connections with computer networks have a weaker impact.
\end{abstract}

Keywords: Exporter; R\&D; Networking; Firm-level data

* Tel.: +81 45339 3563; Fax: +81 45339 3574; E-mail: tomiura@ynu.ac.jp. 


\section{Introduction}

The role of innovation in exporting has been of particular interest in many countries. As the competition with low-wage developing countries has become more intense, manufacturers in industrialized countries need to exert more effort to maintain their international competitiveness. However, R\&D spending within a firm is not the sole solution. Firms can gain ideas or information through direct contacts or computer connections with customers or other firms. This paper examines how internal $R \& D$ and external networking are related with the firm's export decision.

Two lines of literature are closely related with this paper. First, accumulated census-based studies since Bernard and Jensen (1995) have established that exporters are distinctively more productive than non-exporters, but the effect of innovation on exporting has been investigated only among a severely limited number of firms (e.g. Sterlacchini, 1999; Wakelin, 1998). Second, internal R\&D activities and external knowledge networks have been contrasted as the potential sources of innovations (e.g Criscuolo et al., 2005; Freel, 2003; Rogers, 2004; Schmidt, 2005). Combining these two strands of research, this paper compares the importance of R\&D and networking for exporting based on a large firm-level data set. ${ }^{1}$

This paper derives firm-level data from a survey covering 118,300 Japanese manufacturers. A wide range of data are included, such as sales, employment, capital, export, R\&D, patents, subcontracting, foreign subsidiaries, computer network connections, collaborations with other firms, and affiliation with business associations. Furthermore, since firms of any size in all manufacturing industries are included without any firm-size threshold applied, the survey is a relatively accurate representation of the manufacturing as a whole, and suitable for examining whether $R \& D$ is critical for small firms to export. These firm-level

\footnotetext{
1 As a rare example, Nassimbeni (2001) included innovation and consortia affiliation in his analysis of exporting, but concentrated on a limited number of small-sized Italian firms in particular sectors.
} 
investigations will have important policy implications for innovation, export promotion, and SMEs (small and medium-sized enterprises).

This paper is organized as follows. Section 2 describes the firm-level data, and summarizes descriptive statistics comparing exporters vs. non-exporters. Section 3 explains the regression specification. Section 4 reports estimation results. Section 5 concludes.

\section{Descriptive statistics}

\subsection{Description of data}

All the data used for this paper are derived from The Basic Survey of Commercial and Manufacturing Structure and Activity (Sho-Kogyo Jittai Kihon Chosa in Japanese). ${ }^{2}$ The survey contains basic data, such as employment, sales, capital, and exports, as well as a range of corporate variables, such as $R \& D$ expenditure, the number of patents, and the number of subsidiaries overseas. ${ }^{3}$ The firms are surveyed without any firm-size thresholds irrespective of their involvement in exporting or in $\mathrm{R} \& \mathrm{D}$.

The sample size, 118,300 firms, is considerably larger than those previously used for the export-innovation analysis (e.g. 4005 Italian firms by Sterlacchini, 2001; 320 U.K. firms by Wakelin, 1998; 271 Japanese firms by Ito and Pucik, 1993; and 165 Italian firms by Nassimbeni, 2001). This large sample size combined with a wide coverage of firms of any size in all manufacturing industries ensures that this survey provides an accurate representation or replication of all manufacturing in Japan, and is suitable for discussing national innovation or export promotion policies.

\footnotetext{
2 Any researcher can access the same firm data as long as one obtains individual permission from the government in advance.

3 Japan's Census of Manufacturers contains no export data. The Basic Survey of Business Structure and Activities contains export data, but the sample size is around one-tenth of our survey, covering only firms with more than 50 employees and more than 30 million yen of capital.
} 
Although their sample size is large, the census-based plant-level data such as those from U.S. Census of Manufacturers by Bernard and Jensen $(1995,1999)$ contain no innovation data. ${ }^{4}$ The main topic in their studies has been the exporter's productivity premium relative to non-exporters, but the innovation as a source of exporter's advantages has not been investigated. This paper instead evaluates the effects of internal and external sources of innovations to reveal factors behind the high productivity of exporters.

\subsection{Comparisons of Exporters vs. Non-exporters}

Table 1 summarizes descriptive statistics comparing exporters with non-exporters. Several important points emerge from this table.

First, exporters are on average far larger than non-exporters. The number of workers (regular employees) is around ten times larger for exporters, in a comparable range with such previous results as Aw and Hwang (1995). The size disparity is more striking in sales.

Second, exporters tend to be markedly more productive than non-exporters, in line with the established finding (e.g. Bernard and Jensen, 1995). The gap in labor productivity (per-worker sales) is partly attributable to high capital-labor ratio of exporters (per-worker tangible fixed assets). ${ }^{5}$ The capital intensiveness of exporters is consistent with existing international evidence (e.g. Aw and Hwang, 1995; Bernard and Jensen, 1995; Hallward-Driemeier et al., 2002; Wakelin, 1998).

Third, exporters tend to be more active in innovation than non-exporters, corroborating previous research (e.g. Bleaney and Wakelin, 2002; Nassimbeni, 2001; Wakelin, 1998).

\footnotetext{
${ }^{4}$ A Taiwanese data set used by Hwang (2003) covers 123,412 firms, but contains no innovation data. As a rare exception, Aw, Roberts, and Winston (2005) used both export and R\&D data in Taiwan, but their purpose is to examine their complementarity in productivity growth.

${ }^{5}$ The survey contains no data on value-added. Besides, as the data set is in a cross-section format without economic cost data, it is extremely difficult to estimate the total factor productivity.
} 
Although the average $R \& D$ expenditure during the previous year relative to the sales does not differ much, exporters on average own more than ten times more patents than non-exporters. Moreover, the average exporter tends to record official R\&D expenditures or to own a patent considerably more often than the average non-exporter. We must note that all innovative activities may not be recorded as official R\&D expenditures or not be protected by patents, but no other innovation-related data are available in the survey.

Finally, exporters are more likely to have various networking channels. Table 1 presents four measures of networking: (1) using computers connected with networks (inter-firm, open, or local area networks), (2) collaborating with other firms on joint business projects (e.g. joint procurement, storage, shipment, or sales promotion), (3) joining business associations (e.g. local Chamber of Commerce, industry associations, consortia, or business cooperatives), and (4) operating subsidiaries overseas. ${ }^{6}$ The use of computers connected with networks accelerates information flows. Firms are likely to obtain valuable information on export markets, suppliers or competitors through collaborations on joint projects or at meetings of business associations. Foreign subsidiaries facilitate direct contacts with potential export customers, who often provide ideas for adapting product designs to local tastes. Although the average number of foreign subsidiaries does not differ much, ${ }^{7}$ the share of connected firms is much higher among exporters in all four of these networking indicators. ${ }^{8}$ These external knowledge sources are likely to be critical in the firm's export decision.

Before closing this subsection, several notes must be in order. First, the export in the survey is defined as the direct export, for which a firm clears the custom under its own name.

${ }^{6}$ Foreign subsidiaries for this paper are widely defined to include not only majority-owned subsidiaries, minority-owned affiliates, but also plants and branch sales offices.

7 The number is averaged only over firms operating subsidiaries overseas. Foreign subsidiaries are not only complements, but in some cases work as substitutes with exports.

8 Lal (2003) classified 51 Indian firms by the e-business type, and found that the export share of offline firms is low. 
Since many small-sized firms are likely to be involved in exporting indirectly as subcontractors for large-sized direct exporters, Table 1 reports the share of subcontractors. ${ }^{9}$ As expected, non-exporters are more than twice as likely to be involved in subcontracting.

Second, as presented in Table 1, the average exporting firm exports merely one-tenth of its sales. Furthermore, additional evidence, though omitted from the table, strengthens this impression as follows. For nearly half of the surveyed firms, the share of exports in sales is less than two percent. More than sixty percent of the firms export no more than five percent of their sales. Less than five percent of the firms export more than half of their sales. These magnitudes are in a comparable range with that reported for the U.S. by Bernard and Jensen (1995). Based on these observations, this paper concentrates on the firm's binary decision to export or not, rather than investigating the share of exports in sales. ${ }^{10}$

Third, the survey was conducted only once in 1998. While the dynamic aspect of exporting, such as learning-by-exporting by Clerides et al. (1998) and sunk costs by Roberts and Tybout (1997), is another important topic, this paper concentrates on the contrast between exporters vs. non-exporters by exploiting this cross-section data set, as in many previous studies (e.g. Hwang, 2003; Nassimbeni, 2001; Roper and Love, 2002; Sterlacchini, 1999). It is also noted that the surveyed year 1998 was not an exceptional year for Japan's exports, as suggested by the highly stable aggregate exports around this period both in terms of the share in GDP (11\%) and the absolute yen value (merely $0.6 \%$ decline from the previous year). ${ }^{11}$

\subsection{Frequency of exporters and $R \& D$-active firms}

\footnotetext{
${ }^{9}$ The subcontracting in the survey (shitauke in Japanese) is defined by manufacturing tasks outsourced from larger firms.

10 Some previous studies, such as Roper and Love (2002), have confirmed that firm-level variables have significant relations with the binary export decision, not with the export intensity.

11 This decline was after a 14\% rise in 1997. The export declined further in 1999 by 6.1\%, but was followed by $8.6 \%$ rise in 2000, according to trade statistics by the Ministry of Finance.
} 
Table 2 classifies 118,300 firms depending on their participation in exporting and in R\&D. Since large firms are more likely to be active in exporting and R\&D than small firms, this table disaggregates firms according to the firm size. Firms with more than 100 workers are categorized as large-sized firms, while firms with less than 20 workers are small-sized firms. ${ }^{12}$ The following four points found in Table 2 are noteworthy.

First, only a small fraction of firms are exporters. Around six percent $(2.95+3.37 \%)$ of the surveyed firms export their products. This share is in a comparable range with that found in U.S. firms (4.2\% by Bernard et al., 2005). Furthermore, since smaller firms are sampled with lower probability, the share of exporters must be even lower in the true universe of entire Japanese manufacturing firms. ${ }^{13}$ Although some previous studies have reported higher shares, most of them depend on firms above the given threshold size or on plant data. The share of exporters is naturally higher among large firms than among small firms, at the plant level than at the firm level ${ }^{14}$, or in export-dependent economies than in the U.S. or Japan. This low share of exporters is, however, partly because some small-sized Japanese manufacturers supply subcontracted products to large-sized direct exporters, as indicated by the high share of subcontractors among non-exporters reported in Table 1.

Second, more than half $(3.37 /(2.95+3.37))$ of the exporters do not conduct any R\&D at all, though more than ninety-five percent $(80.30 /(3.37+80.30))$ of non-R\&D firms are non-exporters. This suggests that internal $R \& D$ expenditure is not a necessary requirement for exporting, though firms may engage internal innovative activities not captured by official R\&D,

\footnotetext{
${ }^{12}$ Large firms are defined in official statistics by those with 300 or more employees, but these firms occupy less than $1 \%$ in the sample. The share of small firms is comparable with that in Italy according to Sterlacchini (1999).

${ }^{13}$ While all firms with 50 or more employees are surveyed with certainty, firms with less than 50 employees are sampled with varying probability less than one. The difference, however, cannot be rescaled because exact sampling probability of each cell is not disclosed by the government.

${ }^{14}$ Exporting plants are around twice as likely to be part of a multi-plant firm, according to Bernard and Jensen (1995).
} 
such as product quality control, or design improvement. Besides, more than eighty percent (13.38/ (2.95+13.38)) of R\&D-active firms do not export at all, as consistent with our daily observation of some innovative firms concentrating on local markets. Thus, characterizing exporters as R\&D-active firms is an oversimplification.

Third, the participation frequency in exporting and R\&D varies substantially across firm-size classes. While more than half $((1.92+1.15+3.13) / 10.33)$ of large firms are active either in export or R\&D, around ninety percent $(53.81 / 59.27)$ of small firms are non-R\&D, non-exporters. The ratios for medium-sized firms are located somewhere between. This contrast appears consistent with our prior because larger firms are more likely to be active both in exporting and R\&D due to their richer retained earning or human capital.

Finally, in spite of this drastic gap in export participation across different firm-size categories, more than half of exporters are SMEs. Hence, we cannot neglect SMEs in discussing the firm's export decision.

\section{Regression specification}

This paper estimates the following specification relating the probability that the firm exports with various firm-level characteristics and industry dummies.

$$
\begin{aligned}
\operatorname{Pr}\{X>0\} & =\alpha+\beta \ln R \& D / \text { Sales }+\gamma \ln K / L+\delta_{1} C O M+\delta_{2} N S O+\delta_{3} J N T+\delta_{4} A S C \\
+ & \mu_{1} L R G+\mu_{2} S M L+\phi \cdot S U B+\theta \cdot I N D+\varepsilon
\end{aligned}
$$

Included on the right-hand side are the R\&D intensity (R\&D-sales ratio), the capital-labor ratio, four types of network-related variables as explained below, firm-size dummy variables (LRG and $S M L$ ), the dummy for subcontracting $S U B$, and the vector of 3-digit industry dummies $I N D .^{15}$ The error term is expressed by $\varepsilon . R \& D$ intensity and capital intensity are in logarithms. ${ }^{16}$

15 There are 75 industries at the 3-digit level, which is the most detailed classification in the survey. 16 We add a negligible $10^{-8}$ to $R \& D$-sales ratio before taking the logarithm to cover non-R\&D firms. We also add $10^{-8}$ to exports for distinguishing exports which are strictly positive but recorded as 
As accumulated evidence (e.g. Bernard and Jensen, 1999; Clerides et al., 1998) has established that the most efficient firms tend to self-select into exporting, rather than learning-by-exporting, the causality seems to be running from innovation to exporting, not the other way around. Our specification bypasses the problem of directly measuring innovation or productivity, and instead explores internal and external sources of exporter's advantages. We must note, however, that cross-section estimates should not be interpreted as showing the direction of causality.

Networking channels considered in this specification are as follows. First, whether the firm uses computers connected with networks is identified by COM. Second, NSO denotes the number of subsidiaries overseas. ${ }^{17}$ Third, $J N T$ is the dummy variable, taking the value of one if the firm collaborates with other firms on joint business operations. Finally, ASC identifies firms affiliated with a business association. All these inter-organizational relationships are supposed to raise the probability of exporting by expanded knowledge via outside contacts.

While these four variables correspond to external networking channels, the R\&D-sales ratio measures the intensity of internal innovative activity. ${ }^{18}$ Firms active in R\&D are likely to export, as their R\&D tends to raise productivity, reduce costs, or result in new products. The patent-sales ratio is also used alternatively to check the robustness of the results from $R \& D$ flow data. Though all innovation outputs are not necessarily patented, the use of patent data will alleviate the simultaneity problem because the patent is a result of cumulative innovative activities in the past. ${ }^{19}$ Since it is practically impossible to adjust differences in economic

\footnotetext{
"zero" in the survey from unobserved exports of non-exporters. All firms without $K$ data are excluded from regressions.

17 Braunerhjelm (1996) used per-employee fixed assets abroad to examine exports by 73 Swedish firms, but the number of foreign subsidiaries is more appropriate to capture foreign contacts. 18 We must note that internal R\&D and external knowledge are not necessarily substitutes as examined by Veugelers (1997). Previous studies analyzed the relation between these two, but this paper examines how exporting is related with each of these.

19 It is extremely difficult to find appropriate instrumental variables in cross-section data. The
} 
values or depreciation across patents, this paper mainly relies on R\&D flows and uses patent counts for robustness check purposes. ${ }^{20}$

This paper also includes other control variables. $K / L$ is the typical determinant of export in the standard Heckscher-Ohlin factor proportion trade theory. ${ }^{21}$ Capital-intensive firms are supposed to be exporters in Japan, one of the most labour-scarce/capital-abundant countries in the world. Since the survey contains no data on wage, employment disaggregated by skills or occupations, and on training expenditures, the above specification includes no variables for human capital. The effect of $L R G / S M L$ is expected to be positive/negative due to firm-size effects not captured by other variables because larger firms tend to more easily finance fixed entry costs for exporting under capital market imperfection, to spread risks from volatile export operations, or to have advantages due to strong brand name recognition among foreign customers. $^{22}$ The coefficient on SUB is expected to be negative since subcontractors are likely to ship products to exporters, rather than to export them directly on their own.

\section{Estimation results}

\subsection{Basic regression results}

Table 3 reports the regression results from all firms combined. The equation is estimated by logit, but this paper has confirmed that principal results are robust even by probit. Heteroskedasticity-robust standard errors are in parentheses. The following findings are worth noting.

Column (1) presents the estimates for the parsimonious specification focusing on

inter-industry difference in propensity to patent is controlled for by industry dummies.

20 Wakelin (1998) and Basile (2001) count innovations based on original questionnaires, but the difference in value/impact across innovations is not captured even in their studies.

21 Technology-based explanations and factor proportion theory are not mutually exclusive, as discussed in Hirsch and Bijaoui (1985).

22 The data on the firm's age is not available in the survey. 
internal variables. R\&D is significantly related with exporting, confirming the existing evidence (e.g. Basile, 2001; Ito and Pucik, 1993; Sterlacchini, 2001). The capital-labor ratio also has a positive link with exporting, as predicted by the factor proportion trade theory. Large-sized firms are significantly more likely to be exporters than small-sized firms. The involvement in subcontracting work significantly reduces the probability of direct exporting, corroborating the previous results. ${ }^{23}$ These are consistent with the explanation of export behaviour based on factors within individual firm.

Networking variables are included in column (2). All four variables are significantly positively related with exporting. This finding of significant impacts of networking on exporting is in line with related previous work. Nassimbeni (2001) found a positive effect of the consortia affiliation on exports, but his sample was limited to 165 small-sized Italian firms in three particular industries. ${ }^{24}$ While the factor intensity $K / L$ loses its statistical significance, all the other previously included variables remain significant with correct signs. Thus, the simple factor proportion trade theory has weaker explanatory power for firm-level exporting, as compared with the information-based explanations. ${ }^{25}$

Column (3) adds industry-specific dummy variables defined at the most detailed 3-digit level. While the statistical significance of computer networking vanishes, all the other results remain the same as in the previous column. Hence, firms connected with computer networks appear to export more frequently largely because those firms are more likely to be in the industries active in computer networking. ${ }^{26}$ Once industry effects are controlled for, the use of

23 See Nassimbeni (2001), Sterlacchini (1999, 2001), for example.

${ }^{24}$ In related contexts, Criscuolo et al. (2005) found that the coefficient on export declines if information flow variables are added in the knowledge production function of U.K. firms. 25 Wakelin (1998) also reported that the capital intensity was insignificant for the export decision. 26 Lal (2003) added the firm's e-business type, but did not control for innovation in his export regressions. 
network-connected computers does not noticeably stimulate the firm's export decision. ${ }^{27}$ On the other hand, inter-organizational relationships directly contributing to human contacts have significant impacts on exporting.

Finally, column (4) replaces R\&D with patents, as a robustness check. A higher patent-sales ratio is significantly related with a higher probability of exporting. All the other coefficients are virtually unchanged. Consequently, the use of R\&D spending data does not affect our principal conclusions.

\subsection{Large vs. small-sized firms}

Table 4 reports the logit estimation results from three sub-samples disaggregated by firm size. Since very few small-sized firms operate subsidiaries overseas, the number of foreign subsidiaries is included only in the regression over large-sized firms. All the other variables, including industry dummies, are intact. The null hypothesis that coefficients are equal across size classes is strongly rejected at any conventional significance level. ${ }^{28}$ The noteworthy findings are as follows.

First, the effect of R\&D intensity on exporting is evident only among SMEs. This result is consistent with some previous work. ${ }^{29}$ The statistical significance of R\&D-sales ratio vanishes if we concentrate on the variation within large-sized firms. A likely interpretation for this finding may be that higher R\&D intensity is not necessarily critical in overcoming entry barriers to exporting among large firms, who tend to possess a wide range of non-R\&D advantages, such as stronger brand name recognition, extended distribution channels, or richer human capital.

27 This paper has confirmed the insignificance even if computers in stand-alone use are included.

28 A likelihood ratio test based on probit regressions was used. The test statistics are available upon request.

29 For example, Nassimbeni (2001) reported that the export propensity of small firms is strictly linked to their innovation ability. 
This finding is also consistent with our daily observation of SMEs successfully exporting their original, innovative products.

Second, the capital-labor ratio significantly raises the firm's probability of exporting among small firms. Small firms need to be active in physical capital accumulation to overcome their disadvantage in export entry. The previous finding of statistical insignificance of $K / L$ for all firms combined is affected by large firms. The effect of the capital-labor ratio for large firms may be diluted by rich human capital of their workers, for which this paper cannot control due to the data limitation.

Third, the collaboration with other firms on joint business operations has strong effects on exports by large firms, while the affiliation with business associations has strong effects for small firms. ${ }^{30}$ These firm-size variations may be consistent with our daily observations in the following ways. For example, information from other members of business associations is likely to be valuable especially for small firms in deciding to export, but large firms tend to have other wider information sources, such as their foreign subsidiaries. Furthermore, the asymmetry in the effect of joint business operations suggests that large firms often gain rich business experiences valuable for exports by using small firms as subcontractors in practice, if not in name.

Finally, the estimates for other variables are consistent with previous results. For all firm-size classes, working as subcontractors reduces exporting probability, and computer networking has no significant impact on exporting. The operation of more foreign subsidiaries is correlated with higher exporting probability among large-sized firms.

\subsection{Sectoral variations}

In previous regressions, all the coefficients other than those on industry dummies have been

30 Rogers (2004) reported that "networking with other businesses" is related with innovation for small manufacturers in Australia. 
constrained to be equal for all sectors. Since the role of R\&D/networking is likely to vary across sectors, Table 5 reports the sector-specific estimation results. The firms are classified into three sectors, based on the taxonomy of Pavitt (1984). ${ }^{31}$ Among the original taxonomy, the science-based sector (e.g. chemical) and the specialized-supplier sector (e.g. general machinery) are merged because the electronics-related industries are not appropriately classified. The list of industries is provided in Appendix. Within-sector cross-industry variations are controlled for by adding 3-digit industry dummies. The null hypothesis that coefficients are equal across sectors is strongly rejected at any conventional significance level. ${ }^{32}$ The complete specification interacting firm-size dummies with all other main explanatory variables is also estimated for each sector, but its results are not shown for the sake of brevity. ${ }^{33}$ The following sharp contrasts emerge from the table.

First of all, the strongly positive relation with $R \& D$ is evident particularly in the science-based sector. ${ }^{34}$ On the other hand, the export is positively associated with $K / L$ in the supplier-dominated sector, in line with the factor proportion trade theory. ${ }^{35}$ As nearly half of Japanese firms belong to the science-based sector, however, the effect of internal $R \& D$ on export should be emphasized in discussing Japan's exports. This positive relation with internal R\&D in the science-based sector is consistent with the firm-level finding by Schmidt (2005), where not all innovations but innovations triggered by research institutions (e.g. universities) are highly related with the firm's internal R\&D. ${ }^{36}$

31 The taxonomy by Pavitt (1984) has been commonly used in the same context. See Basile (2001), Freel (2004), and Sterlacchini (2001), for example.

32 The likelihood from probit is available upon request.

33 The estimates for the complete specification are available upon request.

34 The estimated effect of R\&D is negative in the supplier-dominated sector, but the complete specification result confirms that it is significantly positive for small firms even in this sector. The $\mathrm{R} \& \mathrm{D}$ effect is also positive in the scale-intensive sector especially for small firms.

35 The effect of capital intensity is significantly positive among small firms in any sector, as shown by the complete specification.

36 The firm-level dataset by Schmidt (2005) has no export data, and depends on only 1,650 firms, all 
Second, the association membership is found to be strongly correlated with exporting for all firms combined in the science-based sector. This finding may partly be due to differences in information disseminated or shared by business association members. For example, information on frontier innovations available through associations is likely to be valuable for firms of any size competing in high-tech industries. ${ }^{37}$

Finally, the estimates for other variables remain stable across sectors, in line with the previous results. Small-sized firms or subcontractors are substantially less likely to be exporters. Joint business operations are positively related with a higher probability of exporting. ${ }^{38}$ The number of subsidiaries overseas is weakly but positively related with the firm's exporting, but computer network connections have no statistically significant impact on the export decision.

\section{Concluding remarks}

While the success in global markets should be a goal for many firms, only a small fraction of firms are actually exporting their products. There is now a large body of empirical evidence which shows that exporters tend to be substantially more efficient than non-exporters. As competition with low-wage developing countries becomes intense in our globalization era, firms in advanced countries are more than ever pressurized to be innovative in order to maintain their competitiveness.

Expanding R\&D expenditure within its self-contained organization is one of the obvious strategies to cope with this globalization challenge. However, several changes in recent years

of which are innovating firms. However, his dataset for investigating internal vs. external innovation sources has much richer information than ours, such as detailed variables on human resources.

37 The complete regression results show that the association coefficient is significantly positive only among small firms in the other two sectors. This may be partly because associations disseminating sector-specific information on foreign markets (e.g. import restriction, product safety regulation) are particularly helpful for SMEs producing low-tech products.

38 The effect of joint business operations is notably weaker among small firms in all three sectors, as consistent with the results reported in the previous section. 
may induce firms to rely more on ideas or information available beyond the firm's boundary. For example, it becomes more and more difficult and riskier to develop all new technologies within a single firm, as the speed of technological changes rises and as a wide scope of technologies becomes more inter-dependent across fields. Furthermore, it becomes less costly to gain information from customers or to interact with other independent firms on joint projects, as information and communication technologies develop. Consequently, this paper has contributed to a better understanding of the advantages of exporters not by analyzing productivity differentials but by evaluating the relative importance of internal and external knowledge sources for the export decision of Japanese manufacturing firms. Particular emphasis has been placed on the intra-sector, inter-firm heterogeneity according to the firm size.

The current paper has confirmed that internal R\&D is significantly positively related with exporting, especially among small-sized firms and in the science-based sector. Exporting in the supplier-dominated sector is positively connected with the capital-labor ratio, indicating that exporters' advantages in this sector are mainly based on physical capital investment. External networking channels, however, also have substantial impacts on exporting. Inter-firm collaborations on joint projects and operations of foreign subsidiaries are highly related with large firms' exporting, while small firms are significantly more likely to export when they are affiliated with business associations. These findings are basically consistent with existing evidence from two lines of previous research explored separately: the relation between exporting and innovation, and the relation between internal $R \& D$ intensity and external knowledge networks in innovation. The export-innovation link has previously been mostly investigated in relation to internal $R \& D$ efforts, but the current paper yields valuable insights how internal and external knowledge sources are interacted with the firm’s export decision.

Substantial contrasts across firm-size categories or across sectors have been revealed in 
our firm-level data covering firms of any size in all manufacturing industries. As many previous studies depended on a severely limited number of firms far from a representation of manufacturing as a whole, the remarkable width of this data set covering 118,300 firms differentiates the current paper from previous research. As our data set is in a cross-section format, however, it will be desirable in future independent studies to find longitudinal data for making causal inferences.

The findings of this paper have important policy implications. For example, public R\&D support for SMEs (small and medium-sized enterprises) should be emphasized when we discuss the nation's international competitiveness. Moreover, promoting affiliations with business associations have also been found to be useful for SMEs to overcome entry barriers to exporting. While many of them are neither exporting nor R\&D-active, SMEs are the dominant firms not only in the whole population but also among exporters. In order to detect specific policy recommendations, however, these results should be supplemented with other data, especially those concerned with the firms' human capital.

\section{Appendix Sectoral disaggregation}

The sectoral definition for Table 5 is as follows. Industries included in the supplier-dominated sector are leather and fur (24), printing and publishing (19), pulp and paper (18), furniture and fixture (17), timber and wooden products (16), apparel (15), textiles (14), beverage, tobacco, and feed (13), and food manufacturing (12). The scale-intensive sector is comprised of transport equipment (31), nonferrous metals (27), iron and steel (26), ceramic, stone, and clay (25), rubber (23), plastics (22), and petroleum and coal products (21). Included in the science-based (or specialized-supplier) sector are precision instrument (32), electric machinery (30), general machinery (29), fabricated metal (28), and chemical (20). The ordnance (33) is merged into general machinery. The miscellaneous manufacturing (34) is excluded from the three sectors. The numbers shown above in parentheses are industry classification codes.

\section{Acknowledgement}

Japan's Ministry of Internal Affairs allowed the author to access the government micro-data 
files by issuing official approvals. Nara Kei, Kazuyuki Motohashi, Junko Sakamoto, and Mutsuharu Takahashi were helpful in arranging this data access. The author deeply appreciates valuable comments from the editor (Ben Martin) and the two anonymous referees of this journal, Craig Parsons, Ryuhei Wakasugi, and workshop participants at Hirosaki University. The research for this paper was partly financed by Grant-in-Aid for Scientific Research. All remaining errors are mine. 


\section{References}

Aw, B., Hwang, A., 1995. Productivity and the export market: a firm-level analysis. Journal of Development Economics 47, 313-332.

Aw, B., Roberts, M., Winston, T., 2005. The complementary role of exports and R\&D investments as sources of productivity growth. NBER Working Paper No. 11774.

Basile, R., 2001. Export behaviour of Italian manufacturing firms over the nineties: the role of innovation. Research Policy 30, 1185-1201.

Bernard, A., Jensen, J.B., 1995. Exporters, jobs, and wages in U.S. manufacturing: 1976-1987. Brooking Papers on Economic Activity: Microeconomics 1995, 67-119.

Bernard, A., Jensen, J.B., 1999. Exceptional exporter performance: cause, effect, or both? Journal of International Economics 47, 1-25.

Bernard, A., Jensen, J.B., Scott, P., 2005. Importers, exporters, and multinationals: a portrait of firms in the U.S. that trade goods. NBER Working Paper No. 11404.

Bleaney, M., Wakelin, K., 2002. Efficiency, innovation and exports. Oxford Bulletin of Economics and Statistics 64, 3-15.

Braunerhjelm, P., 1996. The relation between firm-specific intangibles and exports. Economics Letters 53, 213-219.

Criscuolo, C., Haskel, J., Slaughter, M. 2005. Global engagement and the innovation activities of firms. NBER Working Paper No.11479.

Clerides, S., Lach, S., Tybout, J., 1998. Is learning by exporting important? Micro-dynamic evidence from Colombia, Mexico, and Morocco. Quarterly Journal of Economics 113, 903-947.

Freel, M., 2003. Sectoral patterns of small firm innovation, networking and proximity. Research Policy 32, 751-770.

Hallward-Driemeier, M., Iarossi, G., Sokoloff, K., 2002. Exports and manufacturing productivity in East Asia: a comparative analysis with firm-level data. NBER Working Paper No. 8894.

Hirsch, S., Bijaoui, I., 1985. R\&D intensity and export performance: a micro view. Weltwirtschaftliches Archiv 121, 238-251.

Hwang, A., 2003. Exports, returns to scale, and total factor productivity: the case of Taiwanese manufacturing industries. Review of Development Economics 7, 204-216.

Ito, K., Pucik, V., 1993. R\&D spending, domestic competition, and export performance of Japanese manufacturing firms. Strategic Management Journal 14, 61-75.

Lal, K., 2003. E-business and export behavior: evidence from Indian firms. World Development 32, 505-517. 
Nassimbeni, G., 2001. Technology, innovation capacity, and the export attitude of small manufacturing firms: a logit/tobit model. Research Policy 30, 245-262.

Pavitt, K., 1984. Sectoral patterns of technical change: towards a taxonomy and a theory. Research Policy 13, 343-373.

Roberts, M., Tybout, J., 1997. The decision to export in Colombia: an empirical model of entry with sunk costs. American Economic Review 87, 545-564.

Rogers, M., 2004. Networks, firm size, and innovation. Small Business Economics 22, 141-153.

Roper, S., Love, J., 2002. Innovation and export performance: evidence from the UK and German manufacturing plants. Research Policy 31, 1087-1102.

Schmidt, T., 2005. Absorptive capacity - One size fits all? A firm-level analysis of absorptive capacity for different kinds of knowledge. Discussion Paper No.05-72, ZEW (Center for European Economic Research).

Sterlacchini, A., 1999. Do innovative activities matter to small firms in non-R\&D-intensive industries? An application to export performance. Research Policy 28, 819-832.

Sterlacchini, A., 2001. The determinants of export performance: a firm-level study of Italian manufacturing. Weltwirtschaftliches Archiv 137, 450-472.

Veugelers, R., 1997. Internal R\&D expenditures and external technology sourcing. Research Policy 26, 303-315.

Wakelin, K., 1998. Innovation and export behaviour at the firm level. Research Policy 26, 829-841. 
Table 1

Comparisons of exporters vs. non-exporters

\begin{tabular}{|c|c|c|}
\hline & Exporters & Non-Exporters \\
\hline Firm size: Employment $L$ & 445.8 & 42.3 \\
\hline Sales $Q$ (billion $¥$ ) & 22.94 & 1.26 \\
\hline Productivity (per-worker sales) $Q / L$ & 29.5 & 17.7 \\
\hline Capital-labor ratio $K / L$ & 9.50 & 6.48 \\
\hline R\&D: intensity $R \& D / Q(\%)$ & 3.60 & 2.52 \\
\hline$\%$ of firms conducting $\mathrm{R} \& \mathrm{D}$ & 46.7 & 14.3 \\
\hline Patents: number owned by a firm & 217.5 & 20.4 \\
\hline$\%$ of firms owning patents & 36.2 & 7.1 \\
\hline Computer network (\% of connected firms) & 56.26 & 20.59 \\
\hline Collaboration with other firms (\% of firms) & 64.84 & 8.89 \\
\hline Business associations (\% of affiliated firms) & 65.01 & 9.77 \\
\hline Subsidiaries overseas : \% of operating firms & 27.7 & 1.5 \\
\hline Number of subsidiaries & 18.96 & 13.47 \\
\hline Subcontractors (\% of firms) & 17.74 & 39.67 \\
\hline Export intensity (\% in sales) & 10.84 & 0 \\
\hline
\end{tabular}

Notes: The mean is calculated over firms of which the respective data are available. The original data, except employment or explicitly specified, are in millions of yen. 
Table 2

Percentages of exporters and R\&D-active firms

\begin{tabular}{|c|c|c|c|c|}
\hline & Large firms & Mid-sized firms & Small firms & TOTAL \\
\hline Export and $R \& D$ & 1.92 & 0.79 & 0.24 & 2.95 \\
\hline Export only & 1.15 & 1.38 & 0.85 & 3.37 \\
\hline$R \& D$ only & 3.13 & 5.88 & 4.37 & 13.38 \\
\hline No $X$, No $R \& D$ & 4.13 & 22.36 & 53.81 & 80.30 \\
\hline TOTAL & 10.33 & 30.40 & 59.27 & 100 \\
\hline
\end{tabular}

Notes: Large firms are those with more than 100 workers, while small firms have less than 20 workers. All percentages are relative to all 118,300 firms. 
Table 3

Basic estimation results

\begin{tabular}{|c|c|c|c|c|}
\hline & $(1)$ & $(2)$ & $(3)$ & $(4)$ \\
\hline R\&D/Sales & $0.0408^{* *}$ & $0.0166^{* *}$ & $0.0179 * *$ & --------- \\
& $(0.0030)$ & $(0.0023)$ & $(0.0031)$ & \\
\hline Patent/Sales & --------- & --------- & --------- & $0.0548^{* *}$ \\
& & & & $(0.0042)$ \\
\hline Capital/Labor & $0.0548^{* *}$ & $-0.0146^{*}$ & $-0.0232^{*}$ & $-0.0296 *$ \\
$($ K/L) & $(0.0169)$ & $(0.0110)$ & $(0.0169)$ & $(0.0169)$ \\
\hline LRG & $2.4236^{* *}$ & $1.3494^{* *}$ & $1.5990^{* *}$ & $1.5463^{* *}$ \\
& $(0.0475)$ & $(0.0345)$ & $(0.0514)$ & $(0.0516)$ \\
\hline SML & $-1.7021^{* *}$ & $-1.3350^{* *}$ & $-1.5102^{* *}$ & $-1.5619 * *$ \\
& $(0.0527)$ & $(0.0436)$ & $(0.0588)$ & $(0.0588)$ \\
\hline Subcontractor & $-1.8956^{* *}$ & $-1.5935^{* *}$ & $-1.8302^{* *}$ & $-1.7887 * *$ \\
& $(0.0511)$ & $(0.0363)$ & $(0.0523)$ & $(0.0520)$ \\
\hline Computer & --------- & $0.1127 * *$ & 0.0209 & -0.0520 \\
Networking & & $(0.0310)$ & $(0.0440)$ & $(0.0450)$ \\
\hline Collaboration & ---------- & $1.5783^{* *}$ & $1.6396 * *$ & $1.6107^{* *}$ \\
on joint projects & & $(0.0337)$ & $(0.0463)$ & $(0.0458)$ \\
\hline Affiliation with & --------- & $0.5586^{* *}$ & $0.7026 * *$ & $0.6836^{* *}$ \\
associations & & $(0.0612)$ & $(0.0808)$ & $(0.0810)$ \\
\hline Subsidiaries & --------- & $0.1172^{* *}$ & $0.0782^{* *}$ & $0.0677^{* *}$ \\
overseas & & $(0.0303)$ & $(0.0225)$ & $(0.0216)$ \\
\hline Industry DUM & Yes & No & Yes & Yes \\
\hline Pseudo R ${ }^{2}$ & 0.3930 & 0.3508 & 0.4308 & 0.4340 \\
\hline
\end{tabular}

Notes: 110,987 firms are covered in all cases. The first three explanatory variables are in logarithmic forms. Heteroskedasticity-robust standard errors are in parentheses. The asterisks $* *$ and $*$ denote the significance at $1 \%$ and $10 \%$, respectively. 
Table 4

Estimations disaggregated by firm-size classes

\begin{tabular}{|c|c|c|c|}
\hline & $(1)$ & $(2)$ & $(3)$ \\
& Large firms & Mid-sized firms & Small firms \\
\hline R\&D/Sales & 0.0082 & $0.0168^{* *}$ & $0.0654^{* *}$ \\
& $(0.0066)$ & $(0.0058)$ & $(0.0098)$ \\
\hline Capital/Labor & $-0.1400^{* *}$ & -0.0226 & $0.1620^{* *}$ \\
$($ K/L) & $(0.0363)$ & $(0.0304)$ & $(0.0391)$ \\
\hline Subcontractor & $-0.8581^{* *}$ & $-2.7280^{* *}$ & $-1.2999^{* *}$ \\
& $(0.1152)$ & $(0.0935)$ & $(0.1211)$ \\
\hline Computer & -0.0011 & -0.0146 & -0.1432 \\
Networking & $(0.0943)$ & $(0.0700)$ & $(0.1481)$ \\
\hline Collaboration on & $2.4074^{* *}$ & $2.2048^{* *}$ & 0.1288 \\
joint projects & $(0.1273)$ & $(0.0748)$ & $(0.1418)$ \\
\hline Affiliation with & -0.1469 & $0.5248^{* *}$ & $1.1655^{* *}$ \\
associations & $(0.4164)$ & $(0.1683)$ & $(0.1084)$ \\
\hline Subsidiaries & $0.0726^{* *}$ & --------- & --------- \\
\hline overseas & $(0.0183)$ & & 0.1423 \\
\hline Pseudo $\mathrm{R}^{2}$ & 0.4815 & 0.3437 & 64,295 \\
\hline Number of Firms & 8,421 & 38,261 & \\
\hline
\end{tabular}

Notes: Industry dummies are included in all cases. 10 firms were dropped from estimation due to collinearity. See notes to Table 3. 
Table 5

Sector-specific estimations results

\begin{tabular}{|c|c|c|c|}
\hline & $\begin{array}{l}(1) \\
\text { Supplier-dominated } \\
\text { Sector }\end{array}$ & $\begin{array}{c}(2) \\
\text { Scale-intensive } \\
\text { Sector }\end{array}$ & $\begin{array}{c}(3) \\
\text { Science-based } \\
\text { Sector }\end{array}$ \\
\hline R\&D/Sales & $\begin{array}{c}-0.0302 * * \\
(0.0092)\end{array}$ & $\begin{array}{l}0.0184^{*} \\
(0.0088)\end{array}$ & $\begin{array}{l}0.0313 * * \\
(0.0043)\end{array}$ \\
\hline $\begin{array}{c}\text { Capital/Labor } \\
(K / L)\end{array}$ & $\begin{array}{l}0.1143 * * \\
(0.0328)\end{array}$ & $\begin{array}{c}-0.1746 * * \\
(0.0450)\end{array}$ & $\begin{array}{c}-0.0553^{* *} \\
(0.0231)\end{array}$ \\
\hline$L R G$ & $\begin{array}{l}0.1543 * \\
(0.0959)\end{array}$ & $\begin{array}{l}1.6931 * * \\
(0.1216)\end{array}$ & $\begin{array}{l}2.2002 * * \\
(0.0757)\end{array}$ \\
\hline$S M L$ & $\begin{array}{c}-1.7117 * * \\
(0.1218)\end{array}$ & $\begin{array}{c}-1.6261^{* *} \\
(0.1498)\end{array}$ & $\begin{array}{c}-1.5544^{* *} \\
(0.0779)\end{array}$ \\
\hline Subcontractor & $\begin{array}{c}-0.8400 * * \\
(0.1057)\end{array}$ & $\begin{array}{c}-2.0807 * * \\
(0.1020)\end{array}$ & $\begin{array}{c}-1.9896 * * \\
(0.0746)\end{array}$ \\
\hline $\begin{array}{c}\text { Computer } \\
\text { Networking }\end{array}$ & $\begin{array}{c}0.0572 \\
(0.0948)\end{array}$ & $\begin{array}{c}0.0166 \\
(0.1031)\end{array}$ & $\begin{array}{l}-0.0203 \\
(0.0642)\end{array}$ \\
\hline $\begin{array}{c}\text { Collaboration on } \\
\text { joint projects }\end{array}$ & $\begin{array}{l}2.4754 * * \\
(0.0855)\end{array}$ & $\begin{array}{l}1.6340 * * \\
(0.1241)\end{array}$ & $\begin{array}{l}1.1923 * * \\
(0.0686)\end{array}$ \\
\hline $\begin{array}{c}\text { Affiliation with } \\
\text { associations }\end{array}$ & $\begin{array}{l}0.2442 * \\
(0.1780)\end{array}$ & $\begin{array}{c}-0.3388 * \\
(0.1982)\end{array}$ & $\begin{array}{l}1.0290 * * \\
(0.1042)\end{array}$ \\
\hline $\begin{array}{c}\text { Subsidiaries } \\
\text { overseas }\end{array}$ & $\begin{array}{c}0.0410 \\
(0.0322)\end{array}$ & $\begin{array}{l}0.0471^{*} \\
(0.0300)\end{array}$ & $\begin{array}{l}0.1889 * \\
(0.1222)\end{array}$ \\
\hline Pseudo $\mathrm{R}^{2}$ & 0.3971 & 0.4770 & 0.4536 \\
\hline Number of Firms & 29,937 & 21,851 & 54,413 \\
\hline
\end{tabular}

Notes: The classification of industries into each sector is explained in Appendix. 3-digit industry dummies are included in all cases. See notes to Table 3. 